\title{
ReCEnt InTERnal Migration And Labour Market OUTCOMES: EXPLORING THE 2008 AND 2010 NATIONAL Income Dynamics Study (NIDS) Panel Data IN SOUTH AFrica
}

\author{
Cyril N Mbatha \\ Graduate School of Business Leadership, University of South Africa
}

Joan Roodt

Human Sciences Research Council (HSRC)

Accepted: June 2014

\begin{abstract}
We began with the premise that South African recent migrants from rural to urban areas experience relatively lower rates of participation in formal labour markets compared to local residents in urban communities, and that these migrants are overrepresented in the informal labour market and in the unemployment sector. This means that rural to urban migrants are less likely than locals to be found in formal employment and more likely to be found in informal employment and among the unemployed. Using perspectives from Development Economics we explore the South African National Income Dynamics Study (NIDS) panel datasets of 2008 and 2010, which only provide a perspective on what has happened between 2008 and 2010. We find that while migrants in general experience positive outcomes in informal labour markets, they also experience positive outcomes in formal markets, which is contrary to expectations. We also find that there are strong links between other indicators of performance in the labour market. Earned incomes are closely associated with migration decisions and educational qualifications (e.g. a matric certificate) for respondents between the ages of 30 and 60 years. The youth (15 to 30 years old) and senior respondents (over the age of 60) are the most disadvantaged in the labour market. The disadvantage is further reflected in lower earned incomes. This is the case even though the youth are most likely to migrate. We conclude that migration is motivated by both push (to seek employment) and pull (existing networks or marriage at destination) factors. For public policy, the emerging patterns - indicative and established - are important for informing strategies aimed at creating employment and developing skills for the unemployed, migrants and especially the youth. Similar policy strategies are embodied in the National Development Plan (NDP), the National Skills Development Strategy (NSDS), etc.
\end{abstract}

Key words: rural, migration, unemployment, multinomial logistical model

JEL: 1680

\section{1}

\section{Introduction}

One of South Africa's big socio-economic challenges is its high rate of unemployment. The rate is highest among the youth and among rural dwellers. Rankin and Roberts (2011:128) report that in 2005 "half of those in the labour force cohort aged 15-24 years were unemployed". In the third quarter of 2010 the conservative rate was 49 percent, where "one in every two people below the age of 25 looking for work (was) jobless" (National
Treasury, 2011:13). In many parts of rural provinces like the Eastern Cape, the level of unemployment was in many instances reported to be as high as 60 per cent in 2004. With respect to all tribal-rural regions, a brief to parliamentarians in 2012 warned that, "rural unemployment had risen from 44 per cent in 2009 to 52 per cent (in 2012)" (MG, 2012). Furthermore, what complicates and make the problem worse in rural areas and among the youth are the lack of skills, low levels of school education, lack of work experience and low social capital (Duff \& Fryer, 2005). These 
factors encourage youth migration into urban areas as reported in various quarters (e.g. South African Department of Social Development, 2009). This migration not only leaves rural areas with an aged and vulnerable population but also exacerbates the problem of unemployment in urban areas where competion for scarce work is keen. Similar issues are discussed in detail by Posel (2003, 2004, 2009 and 2010) and Cornwell and Inder (2004), using the NIDS datasets and the October Household Survey (OHS) datasets of the early 1990s, respectively.

Various public policies have been formulated in the last ten years to deal with similar challenges around unemployment and lack of basic and technical skills. While work placement programmes have been aimed directly at reducing youth unemployment and providing the youth with work experiences (HSRC, 2008; McCord, 2008), a renewed discussion on economic development has also been initiated with a focus on rural development and employment issues (Mbatha, 2011). Positive effects of work placement programmes driven by public policy have been reported, at least among the small numbers of youth who find opportunities to participate (HSRC, 2008). Policy has, however, become silent regarding issues of internal and temporary migration, especially the migration of youth from rural areas. Posel (2010:130) expanded on this point, stating that "(i)n the post-apartheid period, where the permanent migration of families into urban areas is no longer prohibited, the persistence of temporary labour migration is perhaps unexpected".

Hence this paper explores the current nature of the links between the challenges posed by rural and urban unemployment and how these may possibly have led to new patterns of recent internal migration, using the first two waves of the National Income Dynamics Study (NIDS 2008 and 2010). In this context, recent internal migration therefore refers specifically to any relocation across the first two waves of the NIDS datasets. Classical and contemporary economic development theories, including those of Lewis (1954), Harris and Todaro (1970), Fields (2005) and Lall, Harris and Shalizi (2006) are used to establish a framework for exploring the data. The paper compares the performances of migrants in the labour market with those of non-migrants. It also explores the effects of explanatory variables including education (e.g. matric ${ }^{1}$ ), age, gender and race on employment status (as the dependent variable). The comparisons are performed using a multinomial logistical model for the employment status, with four categories, which are spelled out explicitly further on in the paper.

Contrary to Cornwell and Inder's (2004) analysis of the 1993 and 1994 OHS datasets, in the NIDS data the performance of rural to urban migrants is not relatively poorer in the formal employment sector compared to that of urban to urban and urban to rural migrants. The odds of finding employment in the informal and formal sectors improve for most migrants, although the odds appear low in informal markets for those moving from urban to rural areas. ${ }^{2}$ Being younger and possessing a matric qualification are also two variables that are substantively associated with observed migration. Being middle-aged (30 to 60 years old) is also associated with a higher likelihood of being able to participate in the labour force. ${ }^{3}$ Meanwhile, the majority of the youth (15 to 30 years old) are unemployed - even though they are the most likely to migrate. It is therefore suggested that migration in general may be influenced not only by push factors but also by the desire to attain some other minimum economic attribute, such as increased educational levels or income. In the 2008 to 2010 NIDS datasets the highest number of migration cases occurred in the age groups 15-30 and 31-45 years. This may be highlighting the effects of both push and pull effects. Some of these patterns form the basis for considerations that public policy, which is aimed at improving the chances of rural and youth employment, should take into account.

The paper is structured in the following manner: In Section 2, the NIDS datasets and research methods are described in broad terms. A review of classical and contemporary theory on migration and economic development is presented in Section 3. Section 4 presents the framework for the analysis. Descriptive statistics are presented in Section 5. Results from the multinomial logistical model exploring the relative chances of being economically inactive, unemployed, informally and formally employed 
are presented in Section 6. A summary discussion with some implications for research and policy is presented in Section 7 .

\section{2}

\section{An overview of the NIDS and methods of analysis}

The data used for analysis come from the 2008 and 2010 NIDS waves (NIDS is a nationally representative panel study). A detailed description of the data collection, collation and release methods and processes is given in Brown, Daniels, De Villiers, Leibbrandt and Woolard (2012) for both waves. It is important to note that the first wave provided the baseline of 28 247 members in total, residing in 7301 households. In the second wave $6 \quad 809$ households with 28641 individual members were interviewed. Of the 28641 members, 21 098 were part of the 2008 cohort and 6591 were new members, who were not part of the first wave. An attrition rate of 21 per cent was reported, with 47.65 per cent due to loss of contact, 37.5 per cent due to refusals for reinterviews and 14.85 per cent because the members were deceased (Finn, Leibbrandt \& Levinsohn, 2012:3-4). Data from the Individual Adult Questionnaires of the two waves formed the basis for the present analysis. The data were analysed as two cross-sectional sets and also merged and analysed as a panel for tracking migrants. The 2010 data were used for identifying most of the socio-economic indicators, including incomes, age, educational level, marital status, etc. The weighting variable provided by the NIDS office was used in running the multinomial model.

The process of creating the two main categorical variables for the multinomial model (namely the variable with four categories of employment status (the dependent variable) and four categories of migration (one of the explanatory variables)) is described in Sections 5 and 6. Other explanatory variables included in the model are gender, age, education, race and marital status. The results were compared to findings by Cornwell and Inder (2004), who used the 1993 and 1994 OHS datasets, and those by Finn, Leibbrandt and Levinson (2012). The primary questions for the research include the following: a) How do different types of migration impact on employment status or labour market outcomes?

b) How do other attributes of respondents, i.e. age, gender, race, education, etc, compare to those of the sample?

c) How do migrants from rural to urban areas, in particular, perform with respect to employment status?

d) How do the results compare to theoretical expectations?

e) What conclusions and policy implications can be drawn with respect to youth migration and education, especially?

\section{3}

\section{Review of the literature}

The divide with respect to living standards across rural versus urban and developed versus developing regions has been the focus of theorising in development economics for more than six decades (see Stern, 1991:122). The works of Lewis (1954), Rostow (1960) and Todaro (1969) form the core of the classical works in the field. Todaro (1997:3) puts it succinctly in saying that the minority of the world's population, constituting only a quarter of the total, live in secured environments of food supplies, shelter, health, etc, while "more than 5.8 billion people have little or no shelter ..., low literacy skills, are unemployed and their prospects for a better life are bleak". In an attempt to understand the dynamics of development and of narrowing inequalities, various theories have been proposed over time. These have included a focus on incentives to invest in human capital and on the migration of low and high skills between rural and urban regions, for example those presented in the Two-Sector Model which was first introduced by Lewis (1954).

\subsection{Rural-urban migration economic development models}

Rostow (1960) highlighted observations of linearly progressive stages to capital accumulation in shifts towards a higher state of development. Others, including Lewis (1954), Todaro (1969), Bhagwati and Srinivasan (1974), Basu (1980), Bond and Wang (1996), have developed theories of skills migration and 
capital investments that are more dynamic in nature. The Lewis (1954) model explained the process of transitioning from an agrarian economy into an industrial one as being fuelled by the migration of low-skilled labour to urban regions. The model proposed that an unlimited supply of low skills would migrate from rural regions where wages are lower into expanding urban centres. This would raise industrial productivity, capital accumulation, technological advancement and profits. The migration from rural areas and the urban industrialisation process would stall when the urban wage incentive disappeared. Some assumptions of the model were that more than 80 per cent of the population resided in rural environments initially, that labour was the only input in the agricultural sector - with a constant technology - while technology changed in urban regions (Todaro, 1997:75-80).

$$
V(0)=\int_{t=0}^{n}[P(t) Y u(t)-Y r(t)] e^{-r t} d t-C(0)
$$

Where:

$\mathrm{V}(0)=$ discounted present value of net gain from rural to urban move

$\mathrm{P}(\mathrm{t})=$ probability of securing an urban job in period $\mathrm{t}$

$\mathrm{n}=$ planning horizon

$\mathrm{Yu} \& \mathrm{Yr}=$ urban and rural average real wage

$\mathrm{C}=$ cost of move

$\mathrm{r}=$ discount rate

Riadh (1998) hence proposed an inclusion of risk aversion, priority hiring, the informal sector - which may offer temporary employment - travel costs, etc as other factors explaining the migration decisions and urban unemployment in the Harris-Todaro model. Potential migrants may, for example, limit risk and delay migration by first investing in education and by spending time establishing networks in urban areas before leaving the rural base. Alternatively, they could use the informal sector as a temporary option while searching for permanent employment (Kochar, 2004, Roberts, 2001; Banerjee, 1991 in Lall, Harris \& Shalizi, 2006).

\subsection{Rural to urban migration patterns in developing countries, including South Africa}

Lall et al. (2006) reported that in Africa during the 1960s and 1970s fifty per cent of urban
Expanding on the Lewis (1954) discussion that migrants respond to urban wages, Harris and Todaro (1970) showed that under certain parameters, such as job stimulation, ${ }^{4}$ the increase in demand for labour in urban areas could lead to unintended urban unemployment, because of an overly responsive rate of migration. Invariably this would reduce national productivity. These effects are known as the Todaro Paradox. Nevertheless, in choosing to migrate to urban areas, risk-neutral agents move because they expect urban wages to be higher than rural wages, the probability of finding a job higher, and the cost of moving low. But the increased labour influx rate would ensure that the real urban wage eventually declines and equals the rural wage, accompanied by rising urban unemployment and zero to negative expected gains from decisions to migrate, as in equation 1 :

growth was due to migration from rural areas and the rate was about 25 per cent in the 1980 s and 1990s. In India 35 per cent of urban growth was due to rural to urban migration of over twenty million people. The figures illustrate the importance and magnitude of rural to urban migration in developing countries. Groups migrate for different reasons. For example, young adults might migrate because of higher expected net returns from migration based on remaining life expectancy; low-skilled individuals may migrate in search of manual jobs; while high-skilled workers may migrate for better jobs. In most developing countries females felt less vulnerable physically in unfamiliar environments than males do. These motivations could be classified into push and pull categories. For example, having good networks in the destination area could be a pull factor. Nonetheless, Lall et al. (2006) have pointed out a number of migration policy questions that remain unanswered for developing countries. These include whether and when migration is desirable, whether and how governments should intervene and what their objectives in doing so should be, given the varied theoretical positions. In South Africa, one of the objectives of the government's National Development Plan (NDP) is to develop the rural economy by including 
agricultural products of emerging farmers in mainstream economic value chains as a means of adding value to boost agricul-tural incomes, wages and employment rates. If successful, such efforts are likely to affect rural to urban migration rates which are based on searches for urban employment and the urban-rural wage differential.

While theoretical and empirical studies have argued that migration to urban areas could be a prerequisite for economic growth and rural development, ${ }^{5}$ migration could also create socio-economic pressures in urban areas. High migration rates have been shown to contribute to high levels of unemployment, a collapse of public service provision, unrest and geographical disparities, if they are not managed effectively. In the light of various arguments, for example that urban unemployment would rise from migration influx, it has been suggested that governments act either on "excess" migration or on the wage incentive. Other suggestions advocate attempts at eliminating inequalities through "rural job creation", "urban job creation" and "urban wage limitation" as proposed by Fields (2005 in Lall et al., 2006:16). Most of the different suggestions are prompted by different assumptions of the models discussed and some may even seem contradictory. For example, while some policy suggestions are aimed at improving urban environments to accommodate higher migration rates, some are aimed at improving rural environments. In earlier theories, for example that of Lewis (1954), it was argued that migration would lead to stability by achieving equilibrium in employment and wage levels across rural and urban areas; later theories (e.g. Field, 2005 in Lall et al., 2006) proposed that the rates would not be stable, with migration continuing beyond some stable levels, because individual motivations vary. This would lead instead to severe social challenges in urban areas and possibly to conflicting interventions. In this sense, the real (or imagined) wage differential between urban and rural areas was not be the only factor in decisions to migrate; there were varying factors, some of which, e.g. study opportunities, had no immediate employment connections (Riadh, 1998; Lall et al., 2006). The inclusion of the informal sector in urban areas as a variable was not always discussed in classical theories. Its predominance, especially in developing countries, has contributed to the discussions of migration beyond the Lewis (1954) model. There has been increasing research on migration alongside the role of the informal sector in developing countries, as illustrated in discussions by Biaroch (1973), Banerjee (1983 \& 1991), Lall et al. (2006), etc. Banerjee (1983), for example, tested models on the informal sector's role in migration processes in India and found "empirical evidence [to] indicate that the migration process postulated in probabilistic models ${ }^{6}$ does not seem to be realistic for the case of Delhi ... Over one-half of the informal sector entrants had been attracted to Delhi by opportunities in this sector itself; actual and potential mobility ... to the formal sector was low". In this sense the informal sector as a variable for exploration has become one of the most important in migration studies beyond the classical twosector model.

In South Africa, migration studies are well documented, ${ }^{7}$ but have shifted focus from migrant-labour issues where legislation controlled the movement of Black labour to urban areas. Posel (2003:2) proposed that "an assumption underlying (the) change in (the) focus seems to be that migrant labour would not be part of a post-Apartheid South Africa ... In the 'new South Africa', people would choose not to be labour migrants but would rather migrate to, and settle permanently at their places of work". She argued that the assumption was not accurate but it had led to a shift towards studies of the extent of immigration, its legality and South Africa's economic and political responses. ${ }^{8}$ She postulated that internal migration had in effect increased partly because of an increase in female labour migration and also because of the changing nature of households, including their internal gender-power relations. "In 1993, an estimated 30 per cent of African migrant workers were women, by 1999 this had increased to 34 per cent" (Posel, 2003:9). And contrary to other surveys, Posel (2009:16) argued that "the NIDS includes a much more comprehensive set of questions on migration and related information than most other nationally representative household surveys in 
South Africa". 9 A discussion that differentiates among different types of migration is useful. However, this paper does not examine the question whether or not internal migration is permanent, for example whether or not people migrate with the intention of returning to their household of origin at some future point. Rather, the paper looks at recent migration from 2008 to 2010, defined as a change of current location. A further implication is that the study has not identified as migrants those individuals who migrated before the 2008 NIDS dataset. For a discussion on the dynamics of migration in the post-Apartheid era, see Posel (2003, 2004, 2009 and 2010).

In exploring the links between rural to urban migration and unemployment, Cornwell and Inder (2004) used the 1993 and 1994 OHS datasets to investigate how South African migrants ${ }^{10}$ would perform in finding jobs compared to non-migrants. Using some of the literature reviewed here, which suggests that migration may actually create urban unemployment, they asked whether recent migrants were more likely to be unemployed or underemployed $^{11}$ when compared to non-migrants with identical attributes. Their expectations were that the outcomes for a migrant were likely to be worse than those for the labour market in general. Among other results they found that:

a) in both the 1993 and 1994 datasets the majority of migrants had moved from urban to urban regions;

b) rural to urban migrants experienced a lower level of unemployment (23 per cent) compared to migrants from urban to rural areas (28 per cent), while non-migrants experienced a rate of 27 per cent in 1994; and

c) the results for all migrants were clearly skewed by the good performance of urban to urban migrants, but overall rural to urban migrants performed marginally better than theoretically expected.

Using the NIDS datasets, Finn, Leibbrandt and Levinson (2012:19) investigated the overall performance of the respondents who had migrated between 2008 and 2010 in comparison with those who had not moved. They found that movers ${ }^{12}$ had gained significantly higher net incomes per capita as against non- movers. They also found that movers had a better chance (at 75.1 per cent) of keeping a job than non-movers (at 71.6 per cent). Fiftysix per cent of previously "discouraged" movers had a job in 2010, compared to only 24 per cent of non-movers. Their message was that migration had positive relative payoffs. This was similar in many ways to Cornwell and Inder's (2004) findings.

Although the present discussion explores migration effects in a similar manner to that of Cornwell and Inder (2004) and Finn et al. (2012), unlike Cornwell and Inder (2004) the study uses different datasets and different variables, for example employment is defined differently in the two studies because the present study does not explore underemployment. In this study attention is also paid to the effects of other variables, including education, gender, age, marital status, etc. The study by Finn et al. (2012) was not based on theories of economic development and it did not differentiate across different types of migration. Using the classical Lewis model, rural to urban migrants would be expected to perform better than non-migrants in rural areas. In the Todaro model, rural to urban migrants would be expected to catch up to urban non-movers in finding similar jobs paying similar wages. Rural to urban migrants may perform much worse than non-movers in urban and rural areas because of socio-economic factors that may lead to their unemployment (Lall et al., 2006). If the informal sector is introduced into the urban environment as a temporary option for migrants (Banerjee, 1983; Kochar, 2004 in Lall et al., 2006), then we could expect to find a higher proportion of rural to urban migrants in informal jobs compared to non-migrants. We can also expect a higher proportion of urban non-migrants in better (or formal) jobs given their advantage with respect to the time needed by migrants to adjust in urban areas. For the same reasons of limited opportunities we could expect recent rural to urban migrants to be mostly unemployed compared to nonmovers in urban settings. Hence, like Cornwell and Inder (2004), we expected rural to urban migrants to perform poorly, especially in formal employment. We therefore explore these possibilities in the two waves of the NIDS by putting three postulations forward: 
1) Compared to local urban residents, migrants from rural to urban areas experience lower rates of formal employment $\left(\mathrm{Pf}<\mathrm{P}^{13}\right)$.

2) The same migrants experience higher rates of informal employment $(\mathrm{Pn}>)$.

3) The migrants are over-represented among the unemployed $(\mathrm{Pu}>\mathrm{u})$.

\section{4}

\section{A formal derivation of the postulations}

Following the Cornwell and Inder (2004) example we derive the three postulations for this study. Their framework uses an implicit assumption of the Harris and Todaro (1970) model, namely that migrants would take over all available jobs in the urban sector. This assumption provides parameters for the model to allow varied potential outcomes for migrants, including our own postulations.

It is assumed that the total labour force (L) at the start of some given year comprises people already in the formal sector $(F)$, those in the informal sector $(\mathrm{N})$ and the unemployed $(\mathrm{U})$ :

$$
\mathrm{L}=\mathrm{F}+\mathrm{N}+\mathrm{U}
$$

For the convenience of partial analysis it is further assumed that the proportions of $\mathrm{F}$ and $\mathrm{N}$ remain constant in $\mathrm{L}$ over time. This means that $\mathrm{f}=\mathrm{F} / \mathrm{L}, \mathrm{n}=\mathrm{N} / \mathrm{L}, \mathrm{u}=\mathrm{U} / \mathrm{L}$, where $\mathrm{f}, \mathrm{n}$, and $\mathrm{u}$ are all constants.

If the rate of rural to urban migration per year $(\lambda)$ is a proportion of the labour force (L) at the start of the year, then it follows that the number of new migrants is $\lambda \mathrm{L}$. This also represents the annual growth rate of $\mathrm{L}$. If the annual turnover in formal urban jobs $(\Upsilon)$ is also a proportion of $F$ then the number of new formal jobs per year is YF. The probabilities of recent migrants becoming formally or informally employed or becoming unemployed can then be considered separately and presented using the following equations.

a) The probability of migrants finding formal employment $(\mathrm{Pf})$ is:

$$
P f=f(Y+\lambda) /(1+\lambda-f(1-Y))
$$

b) The probability of migrants finding an informal job (Pn) is:

$$
P n=n(1-P f) /(1-f)
$$

c) The probability of migrants becoming unemployed $(\mathrm{Pu})$ is:

$$
\mathrm{Pu}=\mathrm{u}(1-\mathrm{Pf}) /(1-\mathrm{f})
$$

Equations (3), (4) and (5) provide the probabilities and parameters of recent migrants becoming formally or informally employed as well as becoming unemployed as they enter urban areas. The parameters allow for more realistic predictions of the rates of migrant participation in the three sectors. While the Harris-Todaro model predicts that recent migrants would take over all new jobs in the urban areas, the parameters allow for differences in the rates of new migrants' employment and unemployment rates versus the rates of the urban labour force.

If in equation (3), $\Upsilon=1$ (meaning that there is a 100 per cent turnover in formal jobs every year), then $P f=f$, which means that every formal job available (i.e. f) is taken by recent migrants (i.e. Pf). We know, however, that if everyone stands an equal chance of becoming employed across all labour markets and also of being unemployed, then not all new jobs will go to recent migrants. A more realistic case to predict would be that $\Upsilon<1$, which would imply that $\mathrm{Pf}<\mathrm{f}$, meaning that the rate of formal employment for recent migrants is lower than the rate for the whole urban community. This is the first postulation (i) made in the preceding section.

If, on the other hand, $\mathrm{Pf}<\mathrm{f}$ then $\mathrm{Pn}>\mathrm{n}$, this means that the rate of employment of recent migrants in the informal sector would be higher than for the whole urban economy. This is the second postulation (ii). Similarly, the rate of unemployment for the recent migrants would be higher than for everybody else in the urban economy $(\mathrm{Pu}>\mathrm{u})$, which is the third postulation (iii).

Using these postulations, the paper explores the NIDS datasets to find out whether migrants and the rural-urban group especially perform better or worse than the urban subsample with respect to labour market participation, including unemployment. $^{14}$ From probabilistic models explored for Indian data in Banerjee (1983) and to some extent discussed in Lall (1991), it is predicted that rural-urban migrants would be overrepresented in the unemployed and informal 
sectors but underrepresented in the formal sector.

\section{5}

\section{Some descriptive statistics}

Some descriptive statistics are presented to expose the more obvious patterns in the data. The gender representation in migration for the whole sample and by migration categories is presented in Table 1. As already mentioned, migration is defined narrowly as detectable ${ }^{15}$ relocations from one geographical area to another between 2008 and 2010. The paper uses the geo-code of Statistics South Africa (SSA) to identify and detect movements across four different types of location, namely:

i) Traditional or tribal area

ii) Rural commercial area

iii) Urban area

4) Urban informal area

The first two location types (i.e. tribal area and rural commercial area) were combined and presented as the rural location and the last two constituted the urban location. The movements across these two broad locations were used to identify relocations and create the migration categories for discussion. Hence the migration discussion does not explore the dynamics of temporary or permanent migration patterns ${ }^{16}$ typical of Apartheid South Africa, some of which are discussed in Posel (2009).

Table 1

Migration by gender

\begin{tabular}{|c|c|c|c|c|c|}
\hline \multicolumn{6}{|c|}{ Migration pattern by gender in $\%$} \\
\hline Gender & $\begin{array}{l}\text { Rural to urban } \\
n=221\end{array}$ & $\begin{array}{l}\text { Urban to rural } \\
\qquad n=131\end{array}$ & $\begin{array}{c}\text { Did not move } \\
n=14301\end{array}$ & $\begin{array}{c}\text { General (all) } \\
\text { migration } \\
n=1632\end{array}$ & $\begin{array}{c}\text { Sample } \\
n=19596\end{array}$ \\
\hline Males & $100(45.25 \%)$ & $51(38.93 \%)$ & $6009(42.02 \%)$ & $735(45.04 \%)^{*}$ & $8311(42.41 \%)$ \\
\hline Female & $121(54.75 \%)$ & $80(61.07 \%)$ & $8292(57.98 \%)$ & $897(54.96 \%)^{*}$ & $11285(57.59 \%)$ \\
\hline
\end{tabular}

Migration patterns with respect to gender show a slight bias towards male migration in the NIDS data. Slightly more men are still likely to relocate compared to women $(+2.02$ per cent versus -3.02 per cent*). ${ }^{17}$ The number of females who move from urban to rural areas, on the other hand, is slightly higher, but the subsample may be too small to be conclusive. The number of people migrating from rural to urban areas is higher than for urban to rural migration, although it is again cautioned that the two subsamples are small $(n=221$ and $\mathrm{n}=131$, respectively) and that only two waves of the NIDS survey have been undertaken.

In Table 2, the distribution of earned incomes ${ }^{18}$ for migration and age categories is presented. For the same migration category, the number of years spent at school is also given, including the number of years for those who did not move and for the whole sample.

Table 2

Median monthly wages (Rands) and years of schooling by migration and age groups

\begin{tabular}{|c|c|c|c|c|c|c|}
\hline \multicolumn{7}{|c|}{ Income by migration and age } \\
\hline \multicolumn{2}{|c|}{ Migration } & Rural to Urban & Urban to Rural & Did not move & All movements & Sample \\
\hline $\begin{array}{l}\text { Earned } \\
\text { income }\end{array}$ & Median & $\begin{array}{c}\text { R } 2050 \\
\text { (Std. 2941) } \\
(n=83)\end{array}$ & $\begin{array}{c}\text { R 2060 } \\
\text { (Std. 3859) } \\
(n=43)\end{array}$ & $\begin{array}{c}\mathrm{R} 1689 \\
(\text { Std. 3507) } \\
(\mathrm{n}=3777)\end{array}$ & $\begin{array}{c}\text { R } 2000 \\
(\text { Std. 3615) } \\
(n=371)\end{array}$ & $\begin{array}{c}R 1800 \\
(S t d 8322) \\
(n=5053)\end{array}$ \\
\hline $\begin{array}{c}\text { Years in } \\
\text { school }\end{array}$ & Median & $\begin{array}{c}11 \\
\text { (Std. 3.89) }\end{array}$ & $\begin{array}{c}11 \\
\text { (Std. 4.30) }\end{array}$ & $\begin{array}{c}9 \\
\text { (Std. 4.93) }\end{array}$ & $\begin{array}{c}10 \\
\text { (Std. 4.59) }\end{array}$ & $\begin{array}{c}9 \\
\text { (Std. 4.85) }\end{array}$ \\
\hline \multicolumn{2}{|c|}{ Age } & $15-30$ years & $31-45$ years & $46-60$ years & $61-76$ years & Sample \\
\hline $\begin{array}{l}\text { Earned } \\
\text { income }\end{array}$ & Median & $\begin{array}{c}\text { R } 1580 \\
(\text { Std. 2452) } \\
(n=1560)\end{array}$ & $\begin{array}{c}R 1900 \\
(\text { Std. 5244) } \\
(n=2053)\end{array}$ & $\begin{array}{c}R 1800 \\
\text { (Std 14465.76) } \\
\quad(n=1315)\end{array}$ & $\begin{array}{c}\text { R } 1435 \\
(\text { Std. 6683) } \\
(n=122)\end{array}$ & $\begin{array}{c}\mathrm{R} 1800 \\
(\text { Std. 8322) } \\
(\mathrm{n}=5053)\end{array}$ \\
\hline $\begin{array}{l}\text { Years in } \\
\text { school }\end{array}$ & Median & $\begin{array}{c}10 \\
(\text { Std. 3.2) } \\
(n=8313)\end{array}$ & $\begin{array}{c}10 \\
(\text { Std. 5.0) } \\
(n=4697)\end{array}$ & $\begin{array}{c}7 \\
(\text { Std.6.8) } \\
(n=3581)\end{array}$ & $\begin{array}{c}3 \\
(S t d .4 .1) \\
(n=2315)\end{array}$ & $\begin{array}{c}9 \\
(\text { Std. } 4.8) \\
(n=19595\end{array}$ \\
\hline
\end{tabular}


With respect to earned income, migrants outperformed everyone else in the sample $(\mathrm{R} 2000>\mathrm{R} 1800)$. Those who did not move had the lowest incomes (R1689). This reinforces findings by Finn et al. (2012), although they looked at welfare gains using the income per capita variable. An increase in age was also associated with increasing earned incomes reaching a maximum (R1900) per month on average for the (31-45) years age group. Incomes dropped markedly after the normal retirement age of 60 years. Hence the lowest earners were either the very young or the very old, as illustrated in Graph 1.

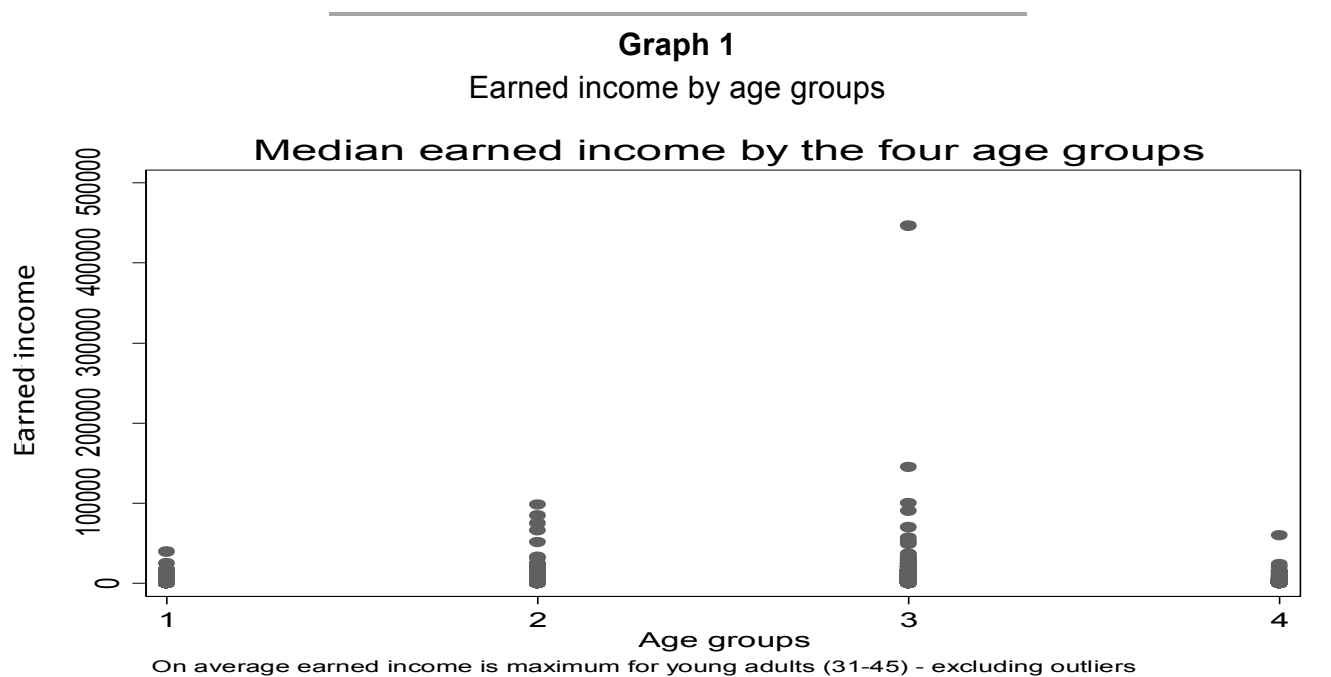

The groups with the lowest average incomes (e.g. above 60 years old) were also more likely to be relatively economically inactive or unemployed, as discussed formally in the next section. Age was also inversely associated with mobility. A higher relative proportion of migration occurred among younger respondents. For example, 58 per cent of $15-$ 30 year-old group migrated, compared to 42 per cent of the whole sample in the same age group, as illustrated in columns 3 and 4 of Table 3. Within the 46-60 years age group, only 11 per cent migrated while this age group comprised 20 per cent of the whole sample. ${ }^{19}$

Table 3

Age groups of non-migrants versus migrants versus total sample

\begin{tabular}{|c|c|c|c|}
\hline \multirow{2}{*}{ Age group } & \multicolumn{3}{|c|}{ Migration } \\
\hline & Did not move & $\begin{array}{c}\text { All types of } \\
\text { migration }\end{array}$ & Total \\
\hline $15-30$ & 5,457 & 1117 & 6,574 \\
& $(39 \%)$ & $\mathbf{( 5 8 \% )}$ & $(42 \%)$ \\
\hline $31-45$ & 3,392 & 514 & 3,906 \\
& $(25 \%)$ & $(\mathbf{2 7 \% )}$ & $(25 \%)$ \\
\hline $46-60$ & 2,937 & 180 & 3,147 \\
& $(21 \%)$ & $(\mathbf{1 1 \% )}$ & $(20 \%)$ \\
\hline 61 and above & 2,012 & 75 & 2,100 \\
& $(15 \%)$ & $\mathbf{( 4 \% )}$ & $13 \%)$ \\
\hline Total & 13,798 & 1,577 & $(100 \%)$ \\
\hline
\end{tabular}

The table shows that with an increase in age, respondents were relatively less likely to migrate. In the formal model presented in Table 5, we also see that the youth (15-30 
years old) are more likely to be unemployed. Young adults (31-45 years old) are more likely to be either formally or informally employed than any other age group. The probabilistic effects of education ${ }^{20}$ on labour market partici- pation are discussed formally in the next section. A breakdown of observations in each of the labour market categories (economically inactive, unemployed, informally employed and formally employed) is presented in Table 4.

Table 4

Labour market by migration categories

\begin{tabular}{|c|c|c|c|c|c|}
\hline \multicolumn{6}{|c|}{ Migration types (percentages in brackets) } \\
\hline $\begin{array}{l}\text { Employment } \\
\text { status }\end{array}$ & Non-movers & All migrants & Rural-urban & Urban-rural & Subsample \\
\hline $\begin{array}{l}\text { Economically } \\
\text { inactive }\end{array}$ & $\begin{array}{r}74848 \\
\quad(59.8)\end{array}$ & $\begin{array}{l}389 \\
(46.0)\end{array}$ & $\begin{array}{l}70 \\
(38.5)\end{array}$ & $\begin{array}{c}37 \\
(24)\end{array}$ & $\begin{array}{l}7981 \\
(58.5)\end{array}$ \\
\hline $\begin{array}{l}\text { Unemployed } \\
\text { (broadly) }\end{array}$ & $\begin{array}{l}1752 \\
(14.0)\end{array}$ & $\begin{array}{l}120 \\
(14.2)\end{array}$ & $\begin{array}{l}35 \\
(19.2)\end{array}$ & $\begin{array}{c}24 \\
(24)\end{array}$ & $\begin{array}{c}1931 \\
(14.2)\end{array}$ \\
\hline $\begin{array}{l}\text { Informally } \\
\text { employed }\end{array}$ & $\begin{array}{l}1263 \\
(10.1)\end{array}$ & $\begin{array}{l}114 \\
(13.2)\end{array}$ & $\begin{array}{l}28 \\
(15.4)\end{array}$ & $\begin{array}{c}8 \\
(8)\end{array}$ & $\begin{array}{l}1413 \\
(10.4)\end{array}$ \\
\hline $\begin{array}{l}\text { Formally } \\
\text { employed }\end{array}$ & $\begin{array}{l}2016 \\
\quad(16.1)\end{array}$ & $\begin{array}{l}222 \\
(26.3)\end{array}$ & $\begin{array}{l}49 \\
(26.9)\end{array}$ & $\begin{array}{l}31 \\
(31)\end{array}$ & $\begin{array}{l}2318 \\
(17.0)\end{array}$ \\
\hline Subsample & $\begin{array}{l}12515 \\
(100.0)\end{array}$ & $\begin{array}{l}845 \\
(100.0)\end{array}$ & $\begin{array}{c}182 \\
(100.0)\end{array}$ & $\begin{array}{l}100 \\
(100.0)\end{array}$ & 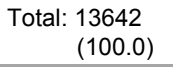 \\
\hline
\end{tabular}

From Table 4 it can be seen that the proportional representation of all migrants (column 3) increased compared to column 2 from the categories of "economically inactive" to "formally employed" and so did the representation of rural to urban migrants. For example, while moving from the unemployed to the formally employed, the percentage of migrants grew in relation to non-migrants. The representation of urban to rural migrants was not systematic and was lowest in informal employment. ${ }^{21}$ Within the labour force, the relative representation of migrants was largest in the formal sector. And in the informal sector it was also larger than the relative representation of non-migrants. These patterns are well captured in the multinomial logistical model, which also provides the levels of statistical significance for each of the variable categories. The indicators of statistical significance (e.g. the p-values) are important because of the small sizes of the migration subsamples in particular. The values are presented in the following section in Table 5 .

In sum, the statistics in Table 1 show that gender had only a minimal influence on migration in general, although migration was still dominated by males, except for urban to rural migration. The subsamples did appear to be small, however. In Table 2, migration is associated with higher earned incomes for migrants than non-migrants. There is also a positive relationship between earned income and age. In Table 3, the youth (15-30 years old) and young adults (31-45 years old) are relatively better represented in groups that migrate than are older respondents. Table 4 shows that all migrants (except for urbanrural) were better represented in the formal and informal employment categories, while a reverse pattern was found for non-migrants.

As previously mentioned, a multinomial logistical model was used to verify the magnitudes and reliabilities of the patterns presented in preceding descriptions against the theoretical postulations made with respect to the labour force. The model explores the log odds $^{22}$ against the economically inactive of participating in different areas of the labour market. For example, they are relative log odds of being,

i) economically inactive for different types of migration, age, gender, marital and race groups with specified levels of school education;

ii) unemployed for the same groups;

iii) informally employed; and

iv) formally employed.

The model predicts, for example, what the relative odds changes would be of a migrant being unemployed compared to being 
economically inactive and relative to the odds facing a non-migrating respondent, etc. The model is, therefore, based on comparisons of chances or odds in employment status for a given group of respondents in comparison with another group (i.e. the dependent base - which in this case is the economically inactive). Table 2 indicated that median earned incomes of migrants (rural-urban and urban-rural) were comparatively higher than those of other groups. Hence the model would predict what the changes in chances are for these groups of being found in any type of employment (from which the earnings were likely to be derived).

\section{6}

\section{Participation in the labour market probabilities}

In this section and throughout the presentation of the multinomial model we explore the magnitude and validity of the three postulations made in Section 4 (i.e. $\mathbf{P f}<\mathbf{f}, \mathbf{P n}>\mathbf{n}$ and $\mathbf{P u}>\mathbf{u})$. The descriptive data in preceding sections are used alongside the model results to support and inform the evaluation and discussion.

\subsection{Changes in the relative odds of being unemployed, informally or formally employed against being inactive}

The NIDS (2008 \& 2010) differentiates between those who are unemployed and those who are employed. It also differentiates among the unemployed in the narrow and broad senses by identifying discouraged job seekers. It also identifies those who are economically active and these form the biggest proportion of the employment status variable, which is the dependent variable in the model. In this discussion, however, it is only the broad definition of unemployment that is adopted. Moreover, a distinction is drawn between those who are formally and informally employed. Firstly, the formal employment variable was derived from indications of written employment agreements and/or formal business registrations. Secondly, the informal employment variable was derived from the presence of verbal work contracts and/or unregistered business. ${ }^{23}$ With the derivation of the variables, the employment status variable was then composed of four categories, namely, the economically inactive, the unemployed, the informally employed and the formally employed.

In other words, the model specifies that the employment status (dependent variable) is made up of four categories, namely:

i) Economically inactive.

ii) Unemployed.

iii) Informally employed.

iv) Formally employed.

The changes in the log odds of being in any one of the above categories depend on the effects of falling within the following categorical or dummy variables (i.e. explanatory variables):

i) Migration (never migrated or general [all types of] migration or rural to urban migration or urban to rural migration).

ii) Gender (male or female).

iii) Age group (15-30 years old [youth] or $31-45$ years old [young adult] or 46-60 years old [mature adult] or over 60 years old [senior]).

iv) Matric (possessing a matric certificate only or no matric).

v) No-education (not having attended school or having some school education). ${ }^{24}$

vi) Married (married or not married).

vii) Race (Black African or Coloured or Indian or White).

A multinomial model with a dependent (y) variable with four categories has three corresponding parts. This is because the first category is used as the base against which the changes in the odds of falling into the other three categories are compared. Additionally, all other explanatory $(\mathrm{x})$ variables which are also categorical in the equation are treated in a similar manner, where the first category is the base for comparing the odds of individuals falling into other categories. Formally, the model specifies that the following:

Employment status $=\mathrm{f}$ (migration; gender; age; possession of matric certificate; possession of zero education; marital status; race), which is:

Ln (P (LM-unemployment))/(P (LMeconomically inactive) $)=b 1+b 2(m=2)+b 3$ 
$(\mathrm{m}=3)+\mathrm{b} 4(\mathrm{~m}=4)+\mathrm{b} 5(\mathrm{~g}=1)+\mathrm{b} 6(\mathrm{age}=2)+$ b7 $($ age $=3)$ b8 $($ age $=4)+$ b9 $($ om $=1)+$ b10 (noeduc $=1)+\mathrm{b} 11(\operatorname{mar}=1)+\mathrm{b} 12(\mathrm{r}=2)+\mathrm{b} 13$ $(\mathrm{r}=3)+\mathrm{b} 14(\mathrm{r}=4)$

Ln (P (LM-informal employment))/(P $($ LM-economically active $))=b 1+b 2(m=2)+$ $\mathrm{b} 3(\mathrm{~m}=3)+\mathrm{b} 4(\mathrm{~m}=4)+\mathrm{b} 5(\mathrm{~g}=1)+\mathrm{b} 6(\mathrm{age}=2)$ + b7 $($ age $=3)$ b8 $($ age $=4)+$ b9 $($ om $=1)+$ b10 $($ no-educ $=1)+\mathrm{b} 11(\operatorname{mar}=1)+\mathrm{b} 12(\mathrm{r}=2)+\mathrm{b} 13$ $(\mathrm{r}=3)+\mathrm{b} 14(\mathrm{r}=4)$

\section{and}

Ln (P (LM-formal employment))/(P (LMeconomically inactive $)=\mathrm{b} 1+\mathrm{b} 2(\mathrm{~m}=2)+\mathrm{b} 3$ $(\mathrm{m}=3)+\mathrm{b} 4(\mathrm{~m}=4)+\mathrm{b} 5(\mathrm{~g}=1)+\mathrm{b} 6(\mathrm{age}=2)+$ b7 $($ age $=3)$ b8 $($ age $=4)+$ b9 $($ om $=1)+$ b10 (noeduc $=1)+\mathrm{b} 11(\operatorname{mar}=1)+\mathrm{b} 12(\mathrm{r}=1)+\mathrm{b} 13$ $(\mathrm{r}=3)+\mathrm{b} 14(\mathrm{r}=4)$

\section{Where:}

Results from the economically inactive group are compared with the results of the unemployed, informally employed and formally employed groups, respectively.

$$
\begin{aligned}
& \mathrm{Ln}=\text { natural log } \\
& \mathrm{LM}=\text { labour market } \\
& \mathrm{P}=\text { probability } \\
& \text { bs = regression coefficients } \\
& \mathrm{m}=\text { migration status } \\
& \mathrm{g}=\text { gender status } \\
& \text { age = age group } \\
& \text { om }=\text { only matric possessed } \\
& \text { no-educ = no education } \\
& \text { mar = marital status } \\
& \mathrm{r}=\text { race }
\end{aligned}
$$

The logistical estimates of the log odds changes in equation (6) are presented in Table 5 below. The overall p-value $<0.001$ of the model tells us that "the model as a whole fits significantly better than an empty model" (Bruin, 2006). In part A of the model, for example, a change in the odds of being unemployed as compared to a change in the odds of being economically inactive (by having migrated to any location - compared to not having migrated) were associated with a 0.1682 point increase, but this was not statistically significant $(p=0.146)$. Overall, migration as a whole did not have statistically significant effects on the status of individuals from being economically inactive to being unemployed. But being female did decrease the relative odds of being unemployed from being economically inactive by -0.1757 points and this was a statistically significant result $(p=0.002)$. Being young (15-30 years old) also had a marked positive effect (0.6748) of reliably $(p=0.000)$ changing the status of individuals from being economically inactive to being unemployed. In short, unlike for those above the normal retirement age of 60 years, being young reliably increased the chances of being unemployed from being economically inactive.

In Part B, migration, especially from rural to urban areas, positively (0.9323) and reliably $(p=0.00)$ affected the chances of being informally employed against remaining economically inactive. Having migrated from an urban to a rural area, on the other hand, decreased those chances (-0.2554), but this pattern was not statistically significant $(\mathrm{p}=0.955)$. Other significant (although marginal) effects on finding informal employment against being inactive came from being in the age groups 15-30 and 31-45 years old, with relative odds of 0.0832 and 0.0945 points, respectively. Being older (above 60 years old) reliably $(p=0.00)$ and markedly decreased the odds by -1.117 points. Possessing a matric also reliably (0.452) improved $(p=0.00)$ the chances of being informally employed against being inactive. But having no education whatsoever on the other limited (-0.247) the likelihood at above a 95 per cent level of confidence $(p=0.018)$. The effects of being informally employed against being economically inactive were negative from being female $(-0.577)$ and the pattern was significant $(p=0.00)$. In essence, having no education had similar effects to being female in the model. Being married was not a significant predictor $(p=0.66)$ of being in informal employment. Only being Coloured reliably $(\mathrm{p}=0.00)$ predicted (by 0.5112 points) improved chances of being informally employed.

In Part C, all migration types improved the chances of finding formal work from being economically inactive reliably ( $\min \mathrm{p}=002$ ) and the improved chances were in the same range ( 0.716 to 0.963 odd points). More so than for informal employment, being female had reliably negative effects on improving chances of being in formal employment (- 
1.083, $\mathrm{p}=0.00)$. The effect was worse than having no education (-0.899). Possessing a matric had the second highest impact (behind a young adult) on improving formal employment chances. Marriage did reliably improve the chances of being formally employed. Again, being a senior ( $>60$ years old) decreased the chances of being in the formal employment sector. Except for Asians, race was also a statistically significant factor in being formally employed. Compared to being Black, for example, being Coloured or White improved individual chances of being formally employed compared to being inactive.

Table 5

Multinomial logistical results

\begin{tabular}{|c|c|c|c|c|c|}
\hline & \multicolumn{4}{|c|}{ Labour market or employment status } & \multirow{2}{*}{$\begin{array}{l}\text { Number of obs }=11887 \\
\text { LR chi2 }(39)=3279.23 \\
\text { Prob }>\text { chi2 }=0.000 \\
\text { Log likelihood }=-11544.169 \\
\text { Pseudo } R^{2}=0.1244 \\
\qquad \begin{array}{c}P \text { value } \\
\left({ }^{*}>90 \% ;{ }^{* *}>95 \% ;\right. \\
>99 \%)\end{array}\end{array}$} \\
\hline & Variable & $\begin{array}{l}\text { Variable } \\
\text { category }\end{array}$ & Coefficient & Standard error & \\
\hline Economically inactive & \multicolumn{5}{|c|}{ (base outcome) } \\
\hline \multirow[t]{20}{*}{ A Unemployed } & Migration & \multicolumn{4}{|c|}{ base $=$ non-migration } \\
\hline & & All migration & 0.1682041 & 0.1155931 & 0.146 \\
\hline & & Rura-urban & 0.4174881 & 0.2216065 & 0.060 * \\
\hline & & Urban-rural & 0.7313968 & 0.2887255 & $0.011^{\star *}$ \\
\hline & Gender & \multicolumn{4}{|c|}{ base $=$ male } \\
\hline & & Female & -0.175764 & 0.0568197 & $0.002^{* * *}$ \\
\hline & Age-groups & \multicolumn{4}{|c|}{ base $=15-30$ years old } \\
\hline & & $31-45$ & 0.6748517 & 0.0709991 & $0.000^{* * *}$ \\
\hline & & $46-60$ & -0.280596 & 0.0929405 & $0.003^{* * *}$ \\
\hline & & Above 60 & -2.133988 & 0.1692709 & $0.000^{* * *}$ \\
\hline & Matric only & \multicolumn{4}{|c|}{ base $=$ no matric } \\
\hline & & Yes & 0.6738075 & 0.0716241 & $0.000^{* * *}$ \\
\hline & Zero education & \multicolumn{4}{|c|}{ base $=$ some education } \\
\hline & & Yes & -0.265091 & 0.1105993 & $0.017^{\star *}$ \\
\hline & Married & \multicolumn{4}{|c|}{ base $=$ married } \\
\hline & & Yes & -0.076584 & 0.0801261 & 0.339 \\
\hline & Race & \multicolumn{4}{|c|}{ Base = Black African } \\
\hline & Coloured & & 0.3787695 & 0.0812777 & $0.000^{* * *}$ \\
\hline & Asian/Indian & & 0.0946028 & 0.2724272 & 0.728 \\
\hline & White & & -0.754045 & 0.3017053 & $0.012^{* *}$ \\
\hline Const. & & & -1.301904 & 0.0531465 & 0.000 \\
\hline \multirow[t]{20}{*}{ B Informally employed } & Migration & & & & \\
\hline & & All migration & 0.6229008 & 0.1247275 & $0.000^{* * *}$ \\
\hline & & Rura-urban & 0.9323562 & 0.2462526 & $0.000^{\star \star \star}$ \\
\hline & & Urban-rural & -0.025540 & 0.454927 & 0.955 \\
\hline & Gender & & & & \\
\hline & & Female & -0.577174 & 0.0641892 & $0.000^{* * *}$ \\
\hline & Age-groups & & & & \\
\hline & & $31-45$ & 1.637275 & 0.0832172 & $0.000 * * *$ \\
\hline & & $46-60$ & 1.128644 & 0.0949569 & $0.000^{* * *}$ \\
\hline & & Above 60 & -1.117069 & 0.1666692 & $0.000^{* * *}$ \\
\hline & Matric only & & & & \\
\hline & & Yes & 0.4519775 & 0.0922506 & $0.000^{* * *}$ \\
\hline & Zero education & & & & \\
\hline & & Yes & -0.247087 & 0.1043584 & $0.018^{* *}$ \\
\hline & Married & & & & \\
\hline & & Yes & 0.0341046 & 0.0778902 & 0.661 \\
\hline & Race & & & & \\
\hline & Coloured & & 0.5111629 & 0.0881343 & $0.000^{* * *}$ \\
\hline & Asian/Indian & & -0.148077 & 0.3266133 & 0.650 \\
\hline & White & & 0.3627149 & 0.2132918 & 0.089 * \\
\hline Const. & & & -2.094782 & 0.0689277 & 0.000 \\
\hline
\end{tabular}




\begin{tabular}{|c|c|c|c|c|c|}
\hline & \multicolumn{4}{|c|}{ Labour market or employment status } & \multirow{2}{*}{ 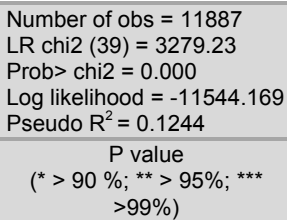 } \\
\hline & Variable & $\begin{array}{l}\text { Variable } \\
\text { category }\end{array}$ & Coefficient & Standard error & \\
\hline \multirow[t]{20}{*}{ C Formally employed } & Migration & & & & \\
\hline & & All migration & 0.716334 & 0.1169931 & 0.000 *** \\
\hline & & Rura-urban & 0.9499513 & 0.2312583 & $0.000^{* * *}$ \\
\hline & & Urban-rural & 0.9639022 & 0.3083955 & $0.002^{* *}$ \\
\hline & Gender & & & & \\
\hline & & Female & -1.083004 & 0.0620088 & $0.000 * * *$ \\
\hline & Age-groups & & & & \\
\hline & & $31-45$ & 1.733811 & 0.0799942 & $0.000^{* \star *}$ \\
\hline & & $46-60$ & 1.191432 & 0.0948392 & $0.000 * * *$ \\
\hline & & Above 60 & -1.570538 & 0.1972201 & $0.000^{* * *}$ \\
\hline & Matric only & & & & \\
\hline & & Yes & 1.536889 & 0.0749345 & $0.000 * * *$ \\
\hline & Zero education & & & & \\
\hline & & Yes & 0.8999681 & 0.1346775 & $0.000^{* * *}$ \\
\hline & Married & & & & \\
\hline & & Yes & 0.4088154 & 0.0754866 & $0.000 * * *$ \\
\hline & Race & & & & \\
\hline & Coloured & & 1.028536 & 0.0788806 & $0.000 * * *$ \\
\hline & Asian/Indian & & 0.1372684 & 0.265886 & 0.606 \\
\hline & White & & 0.4269532 & 0.1847148 & $0.021^{* *}$ \\
\hline Const. & & & -2.125495 & 0.0667204 & 0.000 \\
\hline
\end{tabular}

The model shows that migration (like marital status and being Indian) was not statistically significant ${ }^{25}$ in predicting what will happen to the odds of individuals moving from being economically inactive to being unemployed. Within the labour force, however, many of the chosen variables were statistically significant. In addition, with the exception of being female, much older, and having no education, the variables increased the chances of being either informally or formally employed from being economically inactive. Urban to rural migration surprisingly led to improved chances of finding formal work, but decreased chances of finding informal work. The informal employment pattern was, however, not quite significant at the 95 per cent level of confidence $(p=0.06){ }^{26}$

To visually illustrate the meaning of the coefficients of the model, Graph $2^{27}$ shows the relative predicted probabilities of all four employment status groups against the four migration categories, while holding all other variables constant at their means. The graph can be read alongside patterns presented in Table 5. For example, in Part $\mathrm{C}$ of Table 5 it was reported that the changes in relative $\log$ odds of being formally employed increased from the odds of being economically inactive for migration versus non-migration. This means, for example, that the percentage share of formal employment of migrants (generally) (15.55 per cent) was higher than the percentage share of formal employment of nonmigrants (9.1 per cent). Migrants performed better than non-migrants in formal employment. But with respect to the economically inactive, the share of non-migrants was higher than the share of migrants (i.e. 66.3 per cent $>54.8$ per cent). Similar results are found for the informal sector, where migrants in general (15.6 per cent) outperform non-migrants (10.1 per cent) in terms of respective percentage shares. The percentage shares are presented in the Appendix for all categories in the model and the shares come directly from the model.

If the comparison is drawn between formal employment performances of migrants against unemployment performance of the same migrants the picture is clearer. Migrants in general improve their shares from 14.0 per cent to 15.5 per cent and we have seen that the improvement is significant in Table 5. Nonetheless, graphs similar to Graph 2 can be generated for all other variables to further illustrate the results in Table 5. 


\section{Graph 2}

The marginsplot of the relative probabilities of the four labour market outcomes

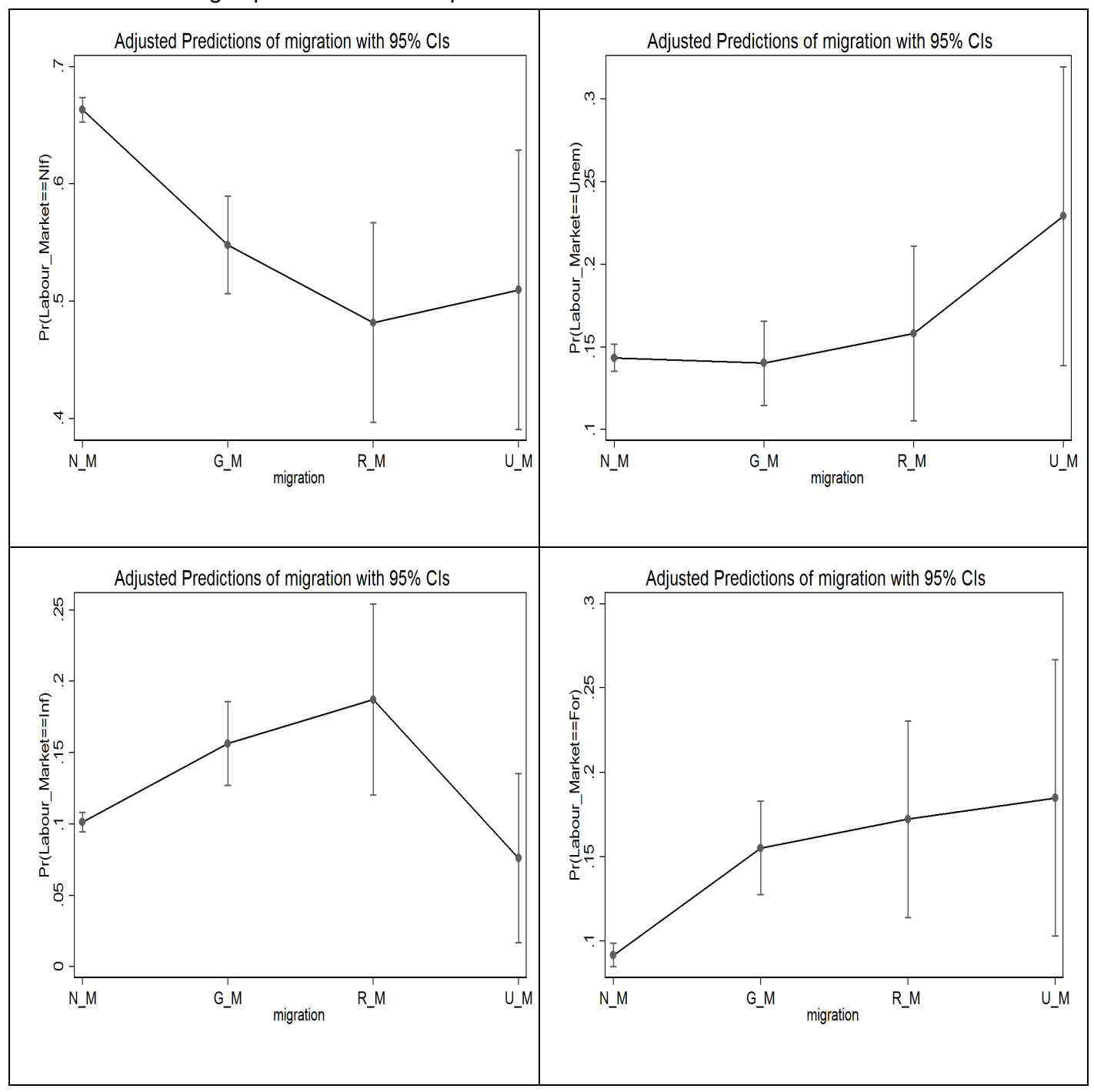

In summary, migration in general led to better labour market outcomes in terms of increased chances of finding formal and informal employment. Migration from a rural to an urban area also led to better opportunities in both formal and informal labour markets, as did the other chosen explanatory variables with the exception of being female, being much older and having no education. With respect to rural to urban migrants, the NIDS data display patterns only partially support the postulations made from theory. For example, rural to urban migrants outperform non-migrants in the informal sector and in the formal sector (i.e. $\mathrm{Pf}>\mathrm{f}$ and $\mathrm{Pn}>\mathrm{n}$ instead of $\mathrm{Pf}<\mathrm{f}$ and $\mathrm{Pn}>\mathrm{n}$ ). Migrants outperformed non-migrants in terms of labour market outcomes; we saw in Table 2 that urban to rural and rural to urban migrants also outperformed other groups with respect to earned incomes (i.e. R2050 > R1800). These people had also spent the highest number of years at school (11 years) compared with all groups combined ( 9 years). In any case, the patterns indicate the interconnectedness of related measures that are generally explored in labour market investigations (i.e. the linkages 
between employment probabilities, incomes, age, gender and education).

Many explored variables had notable positive impacts on the probabilities of finding different types of employment and were also generally statistically significant. It may be important to note that while being young (1530 years old $)^{28}$ was not rewarded highly in the labour market or in terms of earned incomes, having a matric was rewarded highly in terms of formal employment. This observation may be important for policies attempting to link skills acquisition and youth unemployment. This is especially the case because migration was skewed towards the youth and young adults. The youth constituted 58 per cent of those migrating against 39 per cent of the youth who did not migrate.

\section{7 \\ Summary discussion and implications for policy and further research}

The conclusions drawn in the paper take cognizance of the fact that labour market outcomes are not always exogenous to the decisions to migrate. Individuals who have already found work will probably migrate. In those cases individuals would not be migrating without first finding work. Hence, we need to be aware that some of the relationships found in the model could be overestimations, as the model does not control for endogenous factors. From descriptive statistics and the model we found that migration, education (e.g. matric), age and gender variables were the most important both in determining the incomes of respondents and in determining whether or not individuals would be informally or formally employed or unemployed or outside the labour force. Migration effects were often notably positive and statistically significant in predicting the increasing odds of labour market participation.

The descriptive data and model predictions supported only two of three postulations made in the paper. As postulated, all migrants, including rural-urban migrants, were more likely than non-migrants to be unemployed $(\mathrm{Pu}>\mathrm{u})$ as opposed to being outside the labour force, although the results were only stable at $\mathrm{p}=0.06$ or more for rural to urban and urban to rural migrants, respectively. With the exception of urban to rural migrants, all other migrants, including rural to urban, were more likely than non-migrants to be informally employed as against being economically inactive $(\mathrm{Pn}>\mathrm{n})$. The result for urban to rural migrants being informally employed was unstable, however (i.e. $p=0.955$ ). It was surprising to find a high probability of urban to rural migrants to be formally employed against being informally employed (18.5 per cent $>7.6$ per cent). This discussion requires further exploration, as already mentioned. But generally and from postulations it was expected that migrants (including rural-urban migrants) would not be more likely to participate in formal employment than would non-migrants (i.e. $\mathbf{P f}>\mathbf{f}$ ). This emerged strongly from this dataset, as it did from the OHS data (Cornwell \& Inder, 2004).

Although South Africa no longer has direct policy controls on internal migration, as pointed out by Posel (2009), migration was still mostly undertaken by the youth (15-30 years old) and young adults (31-45 years old) compared to people in the dataset over the age of 45 years. From the discussions in the literature it was expected that young people and those who possessed higher levels of education and earned higher incomes and those who were more likely to participate in the labour market formed a cohort that was better prepared to migrate between locations. This relates to the existence of other pull factors, and the point that labour market outcomes are not always exogenous to the decision to migrate. For these groups, the decision to migrate may have posed low levels of risk because of existing pull factors, such as having already found employment at the destination. The implication is that for a number of individuals the decision to migrate was less determined by the quest to find employment (a push factor) than by current endowments (e.g. a high enough level of income from available employment possibilities, compounded by having completed at least a matric). ${ }^{29}$ This may be one of the reasons why Finn et al. (2012:12) found that, irrespective of destination and original location, migrants experienced higher income ${ }^{30}$ 
gains per capita between 2008 and 2010 in the NIDS datasets. The finding is corroborated and made explicit in this paper with respect to all types of migration and for individually earned incomes.

It can be argued that, in this dynamic system, national skills strategies could be formulated at some level to encourage only migrations that would lead to employment opportunities or a completion of some level of education, especially for the youth. Encouraging the youth to complete a matric, for example, whether as migrants or not, would most likely lead to higher chances of their finding work, especially in the formal sector, and might also lead to future migrations. In this sense, the right strategies would create a virtuous circle. While it is possible that a positive effect on one of the variables would have an effect on the whole system, a coordinated policy approach targeting more than one variable would most likely be more effective.

While some patterns have emerged from the NIDS data with respect to recent internal migration, age-related performances in the labour market, incomes, education, etc, it is likely that the patterns will become more significant with the next waves of the study. It would also be productive for other publicly funded national surveys to include modules that would be comparable to the NIDS dataset for higher statistical significance in future results. This point is related to Posel's (2010) arguments about the need for continuing to collect good migration data.

\section{Endnotes}

1 Twelve years of school education

2 Given the small size of the subsample in the 2010 data, the p-values did not indicate statistical significance at a 95 per cent level of confidence.

3 Although the decision to migrate is not estimated in this study, the theoretical proposition also mentioned in this paper is that this decision is influenced by the expected wage variable (Cornwell \& Inder, 2004:2) adjusted for the probability of finding employment.

4 For example, by policy

5 For example, in the case of urban to rural remittances.

6 In these models it is expected that many migrants would take up informal work while waiting for better opportunities to rise in the formal sector (Banerjee, 1983). For example, see Crush (2000) and Spiegel (1980). See Mayer and Mayer (1974) and Stark and Lucas (1985 and 1988) on the discussions of varied motivations for remittances as insurance, for instance.

7 Questions to generate variables on internal migration patterns and remittances also disappeared from national household surveys, including the October Household Survey (OHS).

8 This is especially in relation to information on household membership and transfers of remittances although the NIDS estimates of migrants and their relationships are below those reported in the 1999 OHS and the September rounds of the Labour Force Surveys (LFS) from 2002 to 2005.

9 Cornwell and Inder's (2004) definition of migrants was borrowed directly from the OHS survey question. First, they excluded international migrants to determine whether respondents had moved in the past twelve months and if they had moved, whether they had moved from a rural or urban area, in order to create migration categories similar to those created in this paper. The definition of migration in that work is therefore similar to the definition adopted in this paper in that it did not explore whether or not the recent migration was permanent or temporary. Unlike in the NIDS datasets, however, the OHS survey was not carried out by a panel and did not track the same individuals. The study merely compared results from cross-sectional data between 1993 and 1994.

10 Cornwell and Inder (2004) divided the labour force broadly into the employed and the unemployed. The employed were then divided into those in formal employment and those in informal employment. The unemployed were divided according to the narrow and broad definitions. In the present study the same categories were identified with respect to those in employment but only the broad definition of unemployment was used. Cornwell and Inder (2004) also created a variable of underemployment, which was not created for the present study. The types of questions asked in the NIDS survey relating to the labour force have changed somewhat compared to those asked in the old OHS surveys about twenty years ago. It is acknowledged that the nuanced differences in the definitions of the labour force would limit and compromise a one-to-one comparison exercise across the different surveys. A detailed discussion on the evolution of labour force survey definitions in South Africa and its challenges is presented by Fryer (2013). Nevertheless, the comparisons made between the two studies were performed only for similar variables with respect to the migration definition and the labour force categories. For example, with respect to migration the current analysis does not look into rural to rural migration nor does it look at urban to urban migration.

11 This study did not distinguish between migrant types, e.g. rural to urban migrant versus urban to urban migrant. It also divided the labour force into only three broad categories, namely employed (formally and informally) and unemployed.

12 The performance of rural stayers as against migrant groups is not explored in this paper. From the classical two-sector model, rural non-migrants are expected to have the worst outcomes of all groups. In fact this is the basis of most rural to urban migration theories, except in contexts where the majority of migrants in urban areas find themselves unemployed and without access to land for subsistence farming

13 Cornwell and Inder's (2004) exploration of the 1990s OHS datasets did not include unemployment. 
14 This is taken from the data records that can be made publicly available without risk of compromising the identity of respondents.

15 It is acknowledged that the discussions of such dynamics would have been insightful and their lack is a weakness in the paper.

16 Although almost 58 per cent of the sample (adults 15 years and older) are female, only 55 per cent of migrants are female, hence females are relatively underrepresented among migrants. Although more men still move around, it is not disputed here that female migration has been on the increase in post-Apartheid South Africa, as indicated in Posel (2009).

17 Earned income is used instead of simply the wage, because this study looks at incomes from formal and informal employment and self-employment. From the NIDS data, this is a sum of self-employment, casual and formal net wages.

184559 entries were missing from the whole sample.

19 Not just years at school.

20 A note on this pattern is made in the discussion of the formal model.

21 Where the odds of an event happening are $P /(1-P)$, and where $P=$ Probability of an event happening.

22 These definitions are only approximations of what are really difficult employment categories to discover in real-life labour force surveys, especially with respect to informal employment.

23 In the model, the education dummies compared those with only a matric with those who did not obtain a matric. Those without any education were compared with those with some education.

24 A good signal regarding sampling challenges, including very small samples.

25 With increased sample sizes from future NIDS waves the pattern (if reliable) will need further interrogation. The interrogation would also need to look at what kind of work (formal or informal) is reported predominantly in rural versus urban areas.

26 In Graph 2: Panel 1 = Economically inactive = Top left; Panel 2 = Unemployed $=$ Top right; Panel $3=$ Informal employment = Bottom left; Panel 4 = Formal employment $=$ Bottom right.

27 For ages below 60 years.

28 Refer to Banerjee 1991 in Lall et al. (2006) discussion in Section 3.

29 Household income per capita.

\section{Acknowledgements}

I acknowledge and thank all reviewers for their careful reading and suggestions on improving the paper. Bongiwe Mncwango is acknowledged for her language contributions to the first draft of the paper.

M. Gustafsson is acknowledged for comments on all drafts.

The HSRC/LMIP is acknowledged for its research support.

L Khumalo is acknowledged for reading the first draft.

\section{References}

BANERJEE, B. 1983. The role of the informal sector in the migration process: A test of probabilistic migration models and labour market segmentation for India. Oxford Economic Papers, 35:399-422.

BANERJEE, B. 1991. The determinants of migrating with a pre-arranged job and the initial duration of urban unemployment: An analysis based on Indian data on rural to urban migrants. In Lall, S.V., Harris, S. \& Shalizi, Z. 2006. Rural-urban migration in developing countries: A survey of theoretical predictions and empirical findings. World Bank Policy Research Working Paper 3915, May 2006.

BASU, K. 1980. Optimal policies in dual economies, Quarterly Journal of Economics, 95:187-96.

BHAGWATI, J. \& SRINIVASAN, T. 1974. On reanalyzing the Harris-Todaro model: Policy rankings in the case of sector-specific sticky wages. American Economic Review, 64(3):502-8.

BIAROCH, P. 1973. Urban unemployment in developing countries: The nature of the problem and proposals for its solution. International Labour Organisation, Geneva.

BOND, E.W., WANG, P. \& YIP, C.K. 1996. A general two-sector model of endogenous growth with human and physical capital: Balanced growth and transitional dynamics. Journal of Economic Theory, 68:149-173.

BROWN, M., DANIELS, R.C., DE VILLIERS, L., LEIBBRANDT, M. \& WOOLARD, I. 2012. National income dynamics study wave 2 Beta release user manual. Cape Town: Southern Africa Labour and Development Research Unit.

BRUIN, J. 2006. Newest: command to compute mlogit. UCLA: Statistical Consulting Group. Available at: http://www.ats.ucla.edu/stat/stata/ado/analysis/ [accessed 2014-03-10].

CORNWELL, K. \& INDER, B. 2004. Migration and unemployment in South Africa: When motivation surpasses the theory. Clayton: Monash University.

CRUSH, J. 2000. Migrations past: An historical overview of cross-border movement in Southern Africa. In McDonald, D.A. (ed.) On borders: Perspectives on international migration in Southern Africa. Southern African Migration Project and St Martin's Press:12-25. 
DUFF, P. \& FRYER, D. 2005. Market failure, human capital, and job search dynamics in South Africa: The case of Duncan village. DPRU Working Paper 05/98. Cape Town.

FIELDS, G. 2005. A welfare economic analysis of labor-market policies in the Harris-Todaro model. In Lall, S.V., Harris, S. \& Shalizi, Z. Rural-urban migration in developing countries: A survey of theoretical predictions and empirical findings. World Bank Policy Research Working Paper 3915, May 2006.

FINN, A., LEIBBRANDT, M. \& LEVINSON, J. 2012. Income mobility in South Africa: Evidence from the first two waves of the national income dynamics study, NIDS Discussion Paper 2012/5, Cape Town: National Income Dynamics Study.

FRYER, D. 2013. Contextualising informality in the South African labour market indicators of the limits to evidence-based research? LMIP Working Paper, 7. Available at: http://www.lmip.org.za/sites/default/files/ documentfiles/Contextualising\%20Informality\%20in \%20the \%20South\%20African\%20Labour\%20Market $\%$ 20Indicators $\% 20$ of $\% 20$ the $\% 20$ limits $\% 20$ to $\% 20$ evidence-based $\% 20$ research $\% 20-\% 20$ David $\% 20$ Fryer_0.pdf [accessed 2014-05].

HARRIS J. \& TODARO, M. 1970. Migration, unemployment and development: A two-sector analysis. American Economic Review, 60:126-142.

HUMAN SCIENCES RESEARCH COUNCIL (HSRC). 2008. Employment and learning pathways of learnership participants in the NSDS phase II. Pretoria: Human Sciences Research Council, (Education Science and Skills Development unit).

KOCHAR, A. 2004. Urban influences on rural schooling in India. Journal of Development Economics, 74:113-36.

LALL, S.V., HARRIS, S. \& SHALIZI, Z. 2006. Rural-urban migration in developing countries: A survey of theoretical predictions and empirical findings. World Bank Policy Research Working Paper, 3915, May.

LEWIS W. 1954. Economic development with unlimited supplies of labour. Manchester School of Economics and Social Studies, 22:139-91.

LUCAS, R.E.B. \& STARK, O. 1985. Motivations to remit: Evidence from Botswana. Journal of Political Economy, 93(5):901-918.

MAYER, P. \& MAYER, I. 1974. Townsmen or tribesmen: Conservatism and the process of urbanization in a South African city. Cape Town: Oxford University Press.

MBATHA, N.C. 2011. The relevance of European Union-South Africa trade and the TDCA from a perspective of south Africa's agricultural exports between 1997 and 2008. Agrekon: Agricultural Economics Research, Policy and Practice in Southern Africa, 50(4):75-100.

MCCORD, A. 2008. Training within the South African national public works programme. Human Resource Development Report. Pretoria: HSRC.

MG, 2012. 'Alarming' rise in rural unemployment, MPs told. Mail \& Guardian. Available at: http://mg.co.za/article/2012-09-12-alarming-rise-in-rural-unemployment-mps-told [accessed 2013-05].

NATIONAL TREASURY, 2011. Confronting youth unemployment: Policy options for South Africa. Discussion paper for public comment. Available at: http://www.treasury.gov.za/documents/national\%20 budget/2011/Confronting\%20youth\%20unemployment\%20-\%20Policy\%20options.pdf [accessed 2014-06]. NIDS, 2008 and 2010. National income dynamics study. University of Cape Town. Available at: http://www.nids.uct.ac.za/nids-data/data-access [accessed 2013-04].

POSEL, D. 2003. Have migration patterns in post-apartheid South Africa changed? Paper prepared for Conference on African Migration in Comparative Perspective, Johannesburg, South Africa, 4-7 June. POSEL, D. 2004. Have migration patterns in post-apartheid South Africa changed? Journal of Interdisciplinary Economics, (15):277-292.

POSEL , D. 2009. National income dynamics study (NIDS): Migration: Analysis of the NIDS wave 1 dataset. Discussion Paper No. 1. Durban: University of Kwa-Zulu Natal.

POSEL, D. 2010. Households and labour migration in post-apartheid South Africa. Studies in Economics and Econometrics, 34(3):129-141.

RANKIN, N.I. \& ROBERTS, G. 2011. Youth unemployment, firm size, and reservation wages in South Africa. South African Journal of Economics, 79(2):128-145.

RIADH, B.J. 1998. Rural-urban migration: On the Harris-Todaro model. Maître de conférences à l' université de Bretagne Sud, C.E.I.E., March 1998.

ROBERTS, K. 2001. The determinants of job choice by rural labor migrants in Shanghai. China Economic Review, 12:15-39. 
ROSTOW, W.W. 1960. The stages of economic growth: A non-communist manifesto. Cambridge: Cambridge University Press.

SOUTH AFRICAN DEPARTMENT OF SOCIAL DEVELOPMENT 2009. Migration and urbanisation: Towards a ten year review of the population policy implementation in South Africa (1998-2008).

SPIEGEL, A. 1980. Rural differentiation and the diffusion of migrant labour remittances in Lesotho. In Mayer, P. (ed.) Black villagers in an industrial society. Cape Town: Oxford University Press:109-168.

STARK, O. \& LUCAS, R.E.B. 1988. Migration, remittances and the family. Economic Development and Cultural Change, 36(3):465-481.

STERN, N. 1991. The determinants of growth. Economic Journal, 101(404):122-133.

TODARO, M. 1969. A model of labor migration and urban unemployment in less developed countries, American Economic Review, 59:138-48.

TODARO, M. 1970. Labour migration and urban employment: Reply. American Economic Review, 60(3): 187-188.

TODARO, M. 1997. Urbanisation, unemployment and migration in Africa: Theory and policy, Working Paper no 104. Available at: http://www.popcouncil.org/uploads/pdfs/wp/104.pdf [accessed 2013-04].

\section{Appendix}

Adjusted marginal probability predictions for employment status against migration types

\begin{tabular}{|c|c|c|c|c|c|c|}
\hline \multirow{6}{*}{ Margins of migration categories } & \multicolumn{6}{|c|}{ Number of obs $=11887$} \\
\hline & \multicolumn{3}{|l|}{ LR chi2(39) } & & & \\
\hline & \multicolumn{3}{|l|}{ Prob > chi2 } & & & \\
\hline & \multicolumn{3}{|c|}{ Log likelihood } & & & \\
\hline & \multicolumn{3}{|l|}{ Pseudo R2 } & & & \\
\hline & Margin & Std. E. & z & $P>z$ & \multicolumn{2}{|c|}{ (95\% Conf. Int.) } \\
\hline \multicolumn{7}{|l|}{ Outcome 0 - Economically inactive } \\
\hline Migration & & & & & & \\
\hline N_M & 0.6632457 & 0.0054869 & 120.88 & 0 & 0.6524915 & 0.6739998 \\
\hline G_M & 0.5481114 & 0.021135 & 25.93 & 0 & 0.5066875 & 0.5895352 \\
\hline R_U & 0.4819492 & 0.0434619 & 11.09 & 0 & 0.3967655 & 0.5671329 \\
\hline U_R & 0.5098164 & 0.0608577 & 8.38 & 0 & 0.3905375 & 0.6290952 \\
\hline \multicolumn{7}{|l|}{ Outcome 1 - Unemployed } \\
\hline Migration & & & & & & \\
\hline N_M & 0.1435228 & 0.0041995 & 34.18 & 0 & 0.1352919 & 0.1517536 \\
\hline G_M & 0.1403348 & 0.0130076 & 10.79 & 0 & 0.1148404 & 0.1658291 \\
\hline R_U & 0.158329 & 0.0270336 & 5.86 & 0 & 0.105344 & 0.2113139 \\
\hline U_R & 0.229246 & 0.0460969 & 4.97 & 0 & 0.1388977 & 0.3195943 \\
\hline \multicolumn{7}{|l|}{ Outcome 2 - Informally employed } \\
\hline Migration & & & & & & \\
\hline N_M & 0.1014911 & 0.0034305 & 29.58 & 0 & 0.0947675 & 0.1082148 \\
\hline G_M & 0.1563669 & 0.0149537 & 10.46 & 0 & 0.1270582 & 0.1856756 \\
\hline R_U & 0.1873579 & 0.0341694 & 5.48 & 0 & 0.1203871 & 0.2543287 \\
\hline U_R & 0.0760458 & 0.0302536 & 2.51 & 0.012 & 0.0167498 & 0.1353418 \\
\hline \multicolumn{7}{|l|}{ Outcome 3 - Formally employed } \\
\hline Migration & & & & & & \\
\hline N_M & 0.0917405 & 0.0035708 & 25.69 & 0 & 0.0847419 & 0.098739 \\
\hline G_M & 0.155187 & 0.0140899 & 11.01 & 0 & 0.1275713 & 0.1828026 \\
\hline R_U & 0.1723639 & 0.0297745 & 5.79 & 0 & 0.1140071 & 0.2307208 \\
\hline U_R & 0.1848919 & 0.0417399 & 4.43 & 0 & 0.1030832 & 0.2667005 \\
\hline
\end{tabular}

